\title{
Haudenosaunee Indigenous Knowledge as Reflected in Oren Lyon's “Where is the eagle seat?", an Oration to United Nations
}

\author{
Elisabeth Oseanita Pukan \\ ose@usd.ac.id \\ Department of English Letters, Universitas Sanata Dharma
}

\begin{abstract}
Various problems that people in the world face today, such as environmental and political problems and not to mention human rights issue, cannot all be answered with modern knowledge and technology. In fact, many of these problems are caused by the excess use of technology and some modern values which are not sustainable and not egalitarian. The study about Indigenous knowledge, therefore, is important to be conducted that people may have alternative ways to address world problems. This study attempted to discover the Indigenous knowledge of Haudenosaunee, one of Native American Nations in United States, which is reflected in Oren Lyons' oration entitled "Where is the Eagle Seat?". Anthropological approach is used in this research. Ethnographical data of the Haudenosaunee are utilized to trace the Indigenous knowledge in the oration text. In interpreting the text, the researcher used Paul Ricoeur's interpretation theory from the hermeneutic tradition. This study found six Haudenosaunee Indigenous Knowledge, i.e. justice and equality among people, equality between people and the natural world, earth as a mother and American Continent as Turtle Island, sustainability and concern for future generation, the power of the Creator and the natural law, and unity,. All of these Indigenous values are used by Lyons to address world problems and the problems that Native American people face since the coming of European settlers in their land.
\end{abstract}

Keywords: Haudenosaunee, indigenous knowledge, Chief, faithkeeper

\section{Introduction}

The world problems that people face today are getting more complex and many, ranging from environmental and political crises to the issue of human rights. From those issues, environmental crises happened around the world, such as the vanishing wilderness, pollution, scarcity of resources, and not to mention the impacts of global climate change, are the ones which trigger scientists and policy makers to integrate their science-based knowledge with Indigenous knowledge. They saw that Indigenous knowledge can be a way out for these environmental problems for it has been guiding Indigenous people around the world to live sustainably with the natural world (Vien, 2010).

Realizing the importance of Indigenous knowledge as an alternative ways to solve contemporary world problems, United Nations, as one of global policy makers, took a step to protect the existence of Indigenous knowledge around the world by holding the United Nations Conference on Environment and Development (UNCED). Held in Rio de Janeiro Brazil in 1992, the conference highlighted the urgent need to develop mechanisms to protect the earth's biodiversity and to conserve the knowledge of the environment that is also being lost in many communities (Nakashima \& Roué, 2002). 
Far before the modern scientists and UN realize the importance of Indigenous knowledge as alternative way out to world problem, Native American people in general and Haudenosaunee people in particular, as a matter of fact, has been preserving and practicing their Indigenous knowledge throughout centuries. Moreover, many of their chiefs even incorporate Indigenous knowledge in their orations in international forums, and thus, share it with the international world. Oren Lyons, a Haudenosaunee Chief or Faithkeeper is one of them. When he got a chance to address the United Nations in Geneva in 1977 to advocate the Indigenous people of America, he made use of Haudenosaunee Indigenous value to address the problems of human rights and natural degradation.

Indigenous knowledge has been disregarded until recently, for it has been overshadowed by the promise of modern science and technology (Nakashima \& Roué, 2002). In response to this, through this study, the researcher aspired to elevate the issue of Indigenous knowledge by investigating an oration transcript of Chief Oren Lyons entitled "Where is the Eagle Seat?". In this study, the researcher is not only focusing on the knowledge which is correlated to environmental issue. It is because Indigenous knowledge not only consists of ecological guidance, but also encompasses practices of value systems, worldviews, and ways of life (Nakashima \& Roué, 2002).

\section{Approach and Theory}

The approach to this study is anthropological approach. Within anthropological approach, culture, including Indigenous knowledge, is perceived as the shared set of values, ideas, concepts, and rules of behavior that allow a social group to function and perpetuate itself (Hudelson, 2004). As anthropological approach is used, the researcher use ethnographic data of the Haudenosaunee to identify the Indigenous knowledge in Oren Lyon's oration.

The researcher utilized Paul Ricoeur's interpretation theory from the hermeneutic tradition to decipher Haudenosaunee
Indigenous knowledge contained in Oren Lyons' oration text. Text, according to Ricoeur, is any discourse fixed by writing (Dorairaj, 2000). In this research, Native American orations by Oren Lyons are already fixed into writing through transcription. The researcher took "Where is the Eagle Seat?" from the book The ill A.D. and the Odd Essay by Michael Scharding. Based onthe theory, as these orations are already fixed into writing and became texts, they have gone through a process of distanciation (Dorairaj, 2000). It means that there is estrangement between the texts and the authorial intention; there is separation between the text and the original situation of discourse; and there is split between the text and the original audience (Dorairaj, 2000). Interpretation fills this gap between what a speaker meant in saying something and what her statements mean outside of her intentions (Ghasemi, Taghinejad, Kabiri, \& Imani, 2011).

The step of analysis in Ricoeur's interpretation theory includes explanation, interpretation and understanding. Understanding is more directed towards the intentional unity of discourse (the view of the whole), while explanation is more directed towards the analytic structure of the text (Ricoeur, 1976:74); and in the end, in the understanding process, the interpreter's inner world meets the unique world of each text to create a new picture or understanding of a possible world in the consciousness of the interpreter (Ghasemi et al., 2011).

\section{Indigenous Knowledge}

According to Douglas Nakashima and Marie Roué, Indigenous knowledge systems are the complex arrays of knowledge, knowhow, practices and representations that guide human societies in their innumerable interactions with the natural milieu (Nakashima \& Roué, 2002). The content and nature of Indigenous knowledge extend well beyond the confines of one scientific discipline to encompass not only empirical knowledge, but also practices and know-how, value systems, ways of life and worldviews (Nakashima \& Roué, 2002). 
Indigenous knowledge has several characteristics which differentiate it from western knowledge system, i.e. local, holistic, and oral (Hart, 2010). Local because it comes from specific territory; holistic as Indigenous people do not share the dichotomous western worldview that separates material from the spiritual, nature from culture, and humankind and other life forms (Nakashima \& Roué, 2002); and oral because it is orally transmitted from generation to generation (Vien, 2010). In addition to these three characteristics, Castellano (2000) added two other characteristics, i.e. Indigenous knowledge is experiential (derived from experience) and it is conveyed in narrative or metaphorical language (Hart, 2010).

The characteristic of Indigenous knowledge which needs to be highlighted is the holistic characteristic. Unlike Eurocentric science, Indigenous knowledge does not oppose the secular to the spiritual, and therefore does not oppose the empirical and objective from the sacred and intuitive. Such boundaries in Indigenous knowledge are permeable (Nakashima \& Roué, 2002). 'Science of the concrete' in Indigenous knowledge blends imperceptibly into the metaphysical realm. Indigenous people believe that the concrete and the spiritual coexist side by side, complementing and enriching rather than competing and contradicting (Nakashima \& Roué, 2002).

\section{Native American Indigenous Knowledge}

Gregory Cajete, a Tewa Native American and an Assistant Professor at the University of New Mexico, once wrote that "science" which is used interchangeably with "knowledge" is culturally relative (1999: ix, 4). It means that what is considered science is dependent on

the culture/worldview/paradigm of the definer as human being see and perceives the world through certain paradigm (Cajete, 1999: ix).

Native American science, according to Cajete, operates through different paradigm from Western science. Native American paradigm is comprised of and includes ideas of constant motion and flux, existence consisting of energy waves, interrelationships, all things being animate, space/place, renewal, and all things being imbued with spirit (Cajete, 1999: x). Gary Witherspoon once observed the first idea about motion and flux. He said that the world is in motion and things are undergoing process of transformation, deformation, and restoration (Cajete, 1999: x). This notion led to "spider web" network of relationship which means everything in this world is interrelated; and if everything is interrelated, all of creation is related. Interrelatedness is tied to the idea that everything is imbued with spirit. If human beings are animate and have spirit, all of their relations are also animate and imbued with spirit (Cajete, 1999: $\mathrm{x})$. Spirit and energy waves are the same thing for Native Americans. They believed that all of creation has a spirit or have certain combination of energy waves. What appeared in material world is the manifestation of this combination of energy waves, but on the contrary, not all of energy wave combination manifests themselves into material objects (Cajete, 1999: x).

The other important idea in Native American paradigm is renewal. It is also interrelated to the constant flux explained above. The idea of flux led to Native American understanding of certain pattern in seasons, animal migration, cosmic movement and many others (Cajete, 1999: xi). It led to further concept that the process of creation is a continuous process, but certain regularities that are foundational to our existence must be maintained and renewed (Cajete, 1999: xi).

The concept of land in Native American paradigm is also unique. For Native Americans, the land is very important for events such as patterns and cycles occur at certain places (Cajete, 1999: xi). Each tribal territory has its sacred sites, and its particular environmental and ecological combinations resulting on particular relational networks. All of this happened on Earth. Thus, Native Americans saw the Earth as a sacred entity and they even called it as "Mother", the source of life (Cajete, 1999: xi). 
Those are the paradigm shared among Native Americans which determined how they conceptualize their knowledge. In Native American societies the teaching of this paradigm happens through story telling. Cajete stated that the author of a story does a beautiful holistic treatment of Native American science by giving it "livingness" and spirit. As the author weaves through ecology, relational networks of plants, animals, the land, and the cosmos, the Native American paradigm comes to life (Cajete, 1999: xii).

\section{Haudenosaunee Society and Culture}

Haudenosaunee, which is more wellknown as Iroquois,is a Native American Confederacy consisting of five (later six) Native American Tribes or Nations: Onondaga, Mohawk, Oneida, Cayuga, and Seneca (Rasmussen, 2000: 397). In the early 1700s, Tuscarora Nation joined this confederacy due to war with British colony(Johnson, 2003:7). Before this league of nations is formed, the five Native American Nations were constantly at war. They were one day united by a man named Deganawida whom they later called as the Peace Maker. Deganawida bring the five warring nations the message of peace, reason, law, and the abolishment of war (Gonyea, 1986: 13). He invited the people of the five nations to unite in a confederacy and live under one law. As the people tired of anarchy, they listened to him.

The Haudenosaunee live under The Great Law of Peace (Gayanashagowa) since the day the confederacy was found. This law outlined the path to harmony and unity among the five nations and set out a proper form of government which allowed for the ideas of peace, power and righteousness (Haudenosaunee Iroquois Confederacy). It also declares the basic respect for the rights of all people (Harris \& Johnson, 2009: 3). It guaranteed freedom of assembly, religion, speech and universal suffrage (Gonyea, 1986: 14).

In the Haudenosaunee tribal website, it is written that within the Great Law of Peace text there are three main principles which stand out to govern the rest: peace, power and righteousness. The element of peace means a person's own peace, being of a good mind, and the ability to use the mind to negotiate rather than going to war. In order to have peace one must have balance in their life with health of mind and body (Haudenosaunee Iroquois Confederacy). This peace will lead to the next principle, power. Power does not necessarily mean having power over another. For the Haudenosaunee, power comes from unity. It is by achieving these goals outlined for the Haudenosaunee that they gain the final principle of righteousness. Righteousness is found through living a proper life and following the will of the Creator as set out in the original instructions (Roland J.).

The Basic of Haudenosaunee unit was the extended family. People related by blood and marriage were grouped into clans tracing descent through the female line (Johnson, 2003: 21). Each clan comprised of a head woman, known as a matron, her immediate male and female descendants and the issue (formal or law children) through the female line. Not only is the Haudenosaunee matrilineal, but they are also matrilocalas a marrying couple would live with the wife's family in an extended family longhouse. Each longhouse accommodated up to thirty people, and in a village, there could be from twenty to fifty longhouses (Rasmussen, 2000: 397).

Woman has a special position in Onondaga. The Great Law of Peace instructed that Women shall be considered the progenitors of the Nation. They shall own the land and the soil, and men and women shall follow the status of the mother (Welker, 2014). Not only that, women also play important role in the Haudenosaunee political system since Haudenosaunee chieftainships are held by the Clan Mother of each clan. A chief is selected from the eligible male members of the clan by the Clan Mother in counsel with the female members of the clan and with the agreement of the council (Gonyea, 1986: 25).

For Haudenosaunee, religion was an inseparable part of their daily life (Graymont, 2005: 25). Their religious and ceremonial life is centered on the belief that all beings, 
animals, plant foods, and objects were imbued with power of spirit force otennota, orenda, which flowed through all nature (Johnson, 2003: 22-23), and they sought to keep in the right relationship to them (Graymont, 2005: 25).

Three spirit orders were revealed through analysis of Haudenosaunee prayers. They are spirit forces on earth, a middle level of spirit above the earth, and an upper pantheon of forces controlling the universe (Johnson, 2003: 23). Prayers and thanksgiving songs were addressed to the spirit world and run through the deities upward to the creator. In addition to prayers and thanksgiving, they had rites which were also addressed to the creator and to the spirit of cultivated plants (Johnson, 2003: 23). The Thanksgiving Address is recited in all Haudenosaunee formal occasion except funerals (Johansen \& Mann, 2000: 314). In addition, they also developed a cycle of agricultural thanksgiving ceremonials. Because of the importance of these religious rites for the Haudenosaunee, knowledge of how to perform the proper rituals was therefore essential. These occasions, furthermore, unified the community in a common purpose and way of life (Graymont, 2005: 25).

Like many other Native American Nations, the Haudenosaunee has a creation myth. In Haudenosaunee myth, the first life on earth was brought by a Sky Woman who was fallen down from a sacred tree which grew in the Sky World (Johansen \& Mann, 2000, pp. 86, 87). This Sky World is a physical place that floated among the stars. The father of this Sky Women was dead before she was born. His death was the first ever to occur in Sky World, a spirit sign (Johansen \& Mann, 2000: 87).This Sky Women had an ability to have spiritual conversation with her deceased father, and during one of the conversations, her father's spirit advised her to marry an authority officer of the Sky World known as the Ancient. He is also popularly called "He Holds the Earth" or "The Earth-Grasper" (Johansen \& Mann, 2000: 87). After marrying the Ancient, she was soon with child through the sharing of breath with her husband (Johansen
\& Mann, 2000: 87). One day, the Ancient had a disturbing dream that made him ill. He needed his advisors to catch this dream. The Ancient's advisors saw what was needed to fulfill his dream: to pull up the great tree of Sky World, opening up the magnificent vista on the water world-Earth. Thus, he ordered the tree to be uprooted. Once this was done, its roots pointed to earth, showing the Sky People the way there (Johansen \& Mann, 2000: 87). Having uprooted the tree, the Ancient was thus able to fulfill the second part of his dream that his wife was to fall through the hole in Sky World down to the water world below (Johansen \& Mann, 2000: 88). When the Sky Woman fell, she grabbed wildly at the roots of the upended great tree trying not to fall. Although she was unable to climb up, she managed to hold some seeds from the bountiful tree. In her right hand, she got the seeds of the Three Sisters, i.e. Corn, Beans, and Squash - these would later be the staple food for the Haudenosaunee. She slid down through space and into the atmosphere of Earth (Johansen \& Mann, 2000: 88).

The fall of the Sky Women was noticed by the farsighted Eagle. He noticed all the Elders of earth creature. For the first time, lightning (the Fire Dragon) streaked across the sky of Earth at her side as she hurtled through the atmosphere, while Heron and Loon helped to catch and hold her on their interlocking wings. In the meantime, the Great Tortoise sent around a moccasin which means an emergency council of Elder Animals to see what was to be done. Knowing that the Sky Woman was unable to live on their watery planet, all of the Elder Spirits of Earth creatures quickly agreed that she should not be dropped into the waters. The animals, then, have the idea of diving down to the bottom of the sea for whatever dirt might have clung to its sacred roots. The great Snapping Turtle offered his shell to carry the dirt (earth) and vowed to carry it above him forever as he swam (Johansen \& Mann, 2000: $89,90)$.

Because a small piece of dirt was now ready to accept her, the Birds put the Sky Woman down on her new house, Turtle Island. By using her power, the Sky Women helped the Earth increase in its size. She sang 
medicine chants as she walked in ever increasing circles, spreading the dirt before her until it turned into the great land mass of Turtle Island. Wherever Sky Woman went, every kind of plant sprouted up before her (Johansen \& Mann, 2000: 90). Since then, the Sky Women live on the earth and gave birth to her daughter there. Later, her daughter died after giving birth to two human beings. The Sky Women planted the seeds she grabbed from the sacred tree of the Sky World. From her daughter grave then grew all the plants of life. Corn, Beans, and Squash grew from her breasts, potatoes sprang from her toes, and tobacco grew from her head. The daughter of the Sky Women had transformed into Mother Earth, a living entity (Johansen \& Mann, 2000: 91). That was the Creation Story shared among Haudenosaunee nations; and this creation story was still honored by them and continues to affect their way of life.

\section{Indigenous Knowledge in Oren Lyons' "Where is the Eagle Seat?" Oration 1977}

Representing Native Americans for the first time in international forum, Oren Lyons transmitted several values associated with Indigenous knowledge of the Native American in general and of the Haudenosaunee in particular. The following is the discussion.

\section{a. Justice and Equality among People}

Justice and equality were explicitly mentioned by Oren Lyons in the beginning of his oration. The following quotation is his statement about equality.

"Our nations who have principles of justice and equality, who have respect for the natural world, on behalf of our mother the Earth and all the great elements we come here and we say they too have rights"(Scharding, 2002: 93)

In the quotation above, Oren Lyons described Native American nations to the audiences as "nations who have principles of justice and equality". Furthermore, he mentioned again the value of equality in the middle of the oration as follows.

"We were told in the beginning that we were not human. There are great arguments in the histories of many countries as to the humanness of the Red people of the Western Hemisphere. I must warn you that the Creator made us all equal with one another." (Scharding, 2002: 93)

In the above citation, Oren Lyons mentioned that everybody is created equal by the Creator. Thus, it can be interpreted that for the Haudenosaunee, equal value possessed by every human is inherent, because it is actually given to every human being by the Creator. Another thing which is visible in the quotation above is that Oren Lyons used this idea of equality to promote human rights and to fight against dehumanization experienced by Native American since the coming of European settlers in their continent.

Justice and equality of all people mentioned by Lyons in the oration is actually nothing new for the Haudenosaunee; it is part of their Indigenous knowledge. Justice and equality are two of some principle elements underlying Haudenosaunee constitution or the Great Law of Peace (Lopez \& Lyons, 2001: $6)$. There are three basic principles for the Haudenosaunee, i.e. righteousness, health, and power. Righteousness itself means justice practiced between men and nations, and power which means the authority of law and customs backed by such force as is necessary for justice(Cousins, 2004, p. 4). Meanwhile, equality among nations acknowledged by Haudenosaunee is resulted from the interdependence that developed among the Five Nations following to The Great Law (Cousins, 2004: 4). The welfare and interests of society as a whole became a principal consideration. This, in turn, resulted in members of society developing relationships based upon equality, respect, and regard. Each person retained a significant measure of such rights, but those rights and privileges never exceeded one's duties and responsibilities to others (Cousins, 2004: 4). Furthermore, in Haudenosaunee society, the principle of equality is applied in gender 
relation. Women are not considered as less important than men in Haudenosunee society. As stated earlier, Haudenosaunee women hold special position. They are considered as the progenitors of nation and are the ones who have power to inaugurate male leaders in their community.

\section{b. Equality between People and the Natural World}

Oren Lyons did not only promote equality among people. Although this oration is spoken in the event of UN Conference in Geneva concerning the issue of discrimination toward Indigenous populations of America, Oren Lyons also talked about the principle of equality of all creations and the rights of the natural world as he said,

"Our nations who have principles of justice and equality, who have respect for the natural world, on behalf of our mother the Earth and all the great elements we come here and we say they too have rights." (Scharding, 2002: 93)

Lyons said that they - Lyons along with all Native American delegates, came to represent the natural world, i.e. Mother Earth and all the great elements. It signifies that there is an obligation among Natives American leaders to address environmental issue in the gathering. In the quotation bellow, Oren Lyons repeated the similar statement.

"And it is with this spirit that we come here and we hope that the people and the nations from which we come and to which we will have to return and which we will have to face, whatever they may have in store for our speaking the truth on behalf of people, of the world, of the four-footed, of the winged, of the fish that swim. Someone must speak for them.I do not see a delegation for the four-footed. I see no seat for the eagles." (Scharding, 2002: 93)

In the last sentence, Lyons affirmed that there is no representation for living beings other than human in the conference. It is a metaphor through which he implied that the interest or the welfare of the natural world now have no place in the decision making of human beings. People now forget to think about the consequences of their action to the natural world. They tend to forget their actual place in the universe. The following statement also reflects this inclination.

"We forget and we consider ourselves superior, but we are after all a mere part of the Creation. And we must continue to understand where we are. And we stand between the mountain and the ant, somewhere and only there, as part and parcel of the Creation." (Scharding, 2002, p. 93)

Oren Lyons' avowed the arrogance of people in the above statement that they assume themselves superior than any other creatures. In fact, according to Lyons, human being is actually just a part of a bigger creation.

The view that human being is superior to the rest of creations does not fit to Haudenosaunee worldview. In their perception, all life is equal, including the birds, animals, things that grow, and things that swim; and it is the Creator who presents this reality (Lyons, 1991: 203). Furthermore, one of Haudenosaunee fundamental laws is to treat all elements of natural world with respect and they acknowledge those elements as equal component of their lives on earth (Hill, 2004). This concept of equality of all beings does not only exist in Haudenosaunee traditions. It is a basic concept believed by Native American in general. The communal consciousness of Native American communities is extended to and included the natural world in an intimate and mutually reciprocal relationship. Members of Native American communities connected themselves to the plants, animals, waters, mountains, sun, moon and stars through clan and societal symbolism, ritual, art, and tradition (Cajete, 2000 , p. 95). This idea of communal consciousness extended to include the natural world is related to Native American paradigm that all creations have "spider web" network relationship as explained by Cajete (1999, p. x). This form of relationship means that human being is interrelated with other forms of creation, including the animals, plants, and the land. 
Human beings indeed have special quality compared to other creations. They have been gifted with life to evolve spiritually through the material experience (Cousins, 2004). They have free will which allows them to make choices that release them from acting in a purely instinctual or impulsive manner. Being gifted with free will, human beings have a responsibility to use it in a commendable manner (Cousins, 2004). Those who do, treat all things - including the natural elements, with honor and respect. This concept is reflected in Oren Lyons' further utterances when he said that people have been given mind so that they have responsibility to take care the natural world. Here is the statement.

It is our responsibility, since we have been given the minds to take care of these things. The elements and the animals, and the birds, they live in a state of grace. They are absolute, they can do no wrong. It is only we, the two-legs that can do this. And when we do this to our brothers, our own brothers, then we do the worst in the eyes of the Creator." (Scharding, 2002: 93)

The last sentence of the quotation above shows again the communal consciousness of Native American which include natural elements. In that sentence, Lyons referred to the animals as the people's relatives, i.e. brothers. Trees are not just trees for Native Americans, they were seen as relatives, and so were other species. They were relatives who watched human being all the time to see how human beings were handling the remains of plants and animals. Because of this belief, Native Americans have to show respects for them (Martinez, Salmon, \& Nelson, 2008, p. 92). Respect and looking at material elements as relation is also reflected in the way Lyons referring to the earth. In his oration, he called the earth as "our mother" or "Mother Earth".

\section{c. The Earth as a Mother and American Continent as Turtle Island}

In the oration, Oren Lyons referred to the America continent as Turtle Island when he introduced himself and his fellow Native
Americans delegates. He also called the earth as "Mother Earth". Here is his statement.

Of the Red brothers of the Western Hemisphere, of the two great turtle islands a certain few of us have been given a short time and a great task to convince you that we too are human. And have rights. Our nations who have principles of justice and equality, who have respect for the natural world, on behalf of our mother the Earth and all the great elements we come here and we say they too have rights (Scharding, 2002: 93).

From the quotation, the researcher interpret that two Turtle islands signifies North and South American Continents as Native North Americans were joined by Native South Americans in this 1977 UN event. Referents of Turtle islands to signify America and Mother Earth to signify the earth show that as Native American, Oren Lyons was still holding on Native American myth, specifically Haudenosaunee Creation Story, even when he was speaking in international forum. As has been discussed previously, there was a belief that American continent was formed becausea turtle offers its shell to carry the mud gathered by animals to save the Sky Women from falling into the water. The turtle vowed to carry the Earth above him forever as he swam (Johansen \& Mann, 2000: 89, 90). The myth also told that the daughter of the Sky Women became Mother Earth after her death. It was from her grave that plants sustaining human beings' existence grows (Johansen \& Mann, 2000: 91).

Referents Turtle Island and Mother Earth show that as a Haudenosaunee faithkeeper, Oren Lyons continued to see the American land and the earth through the eyes of tradition. This tradition, though may sound absurd for modern society, has great positive consequences for the environment. This mythmade the Haudenosaunee to become constantly conscious of the fact that human being existencein this world is not something that can be taken for granted. The Mother Earth can be seen as nature which provide for the lives of all living things. It is from the environment that people get the food they 
eat, the water they drink, and the fresh air they breathe. Therefore, people need to pay it back by treating the environment with great care.

\section{d. Sustainability and Concern for Future Generations}

Oren Lyons did not only address the issue of Native American rights in his oration. $\mathrm{He}$ also addressed the rights of the future generation in the following statement.

"The future generations, our children, our grandchildren, and their grandchildren are our concern. That they may have clean water to drink that they may observe our four-footed brothers before they are extinct, that they may enjoy the elements that we are so fortunate to have and that serves us as human beings."(Scharding, 2002: 93)

The above quotation demonstrates that Native Americans have awareness to think about the fate of the upcoming generation. The idea that the future generation may enjoy the natural elements enjoyed by the society today shows that for Native Americans, the generations to come have equal rights with the present generation.

The consciousness about the welfare of the coming generation exists in Haudenosaunee culture. In their Great Law of Peace article twenty eight, the Peace Maker asked every Confederate Lord to look and listen for the welfare of the whole people and have always in view not only the present but also the coming generations. This concept appears again in the article fifty seven which says that the Five Nations shall be united completely and enfolded together, united into one head, one body and one mind so that they shall labor, legislate and council together for the interest of future generations (Welker, 2014). It shows that since the day of the founding of Haudenosaunee Confederacy, they were given a duty by the Peacemaker to ensure the welfare of future generation.

In the oration, Oren Lyons made further argument related to the rights of the upcoming generations, i.e. their well-being can be attained only if people understand the principle of equality of all life. Here is the statement.

"And not only human beings, but all life is equal. The equality of our life is what you must understand and the principle by which you must continue on behalf of the future of this world.Economics and technology may assist you, but they will also destroy you if you do not use the principles of equality. Profit and loss will mean nothing to your future generations."(Scharding, 2002: 93)

The essence of the above statement is the importance of sustainability for the future of the world, for future generations. This sustainability can only be achieved if people use the principle of equality.

Economics and technology mentioned by Oren Lyons are inseparable part of our society today which is actually prone to natural exploitation. However, according to Lyons, this natural exploitation will not happen if people have respect for the natural world and acknowledge that all forms of life are equal. This respect and understanding of equality of all forms of life will not only bring harmony between people and the natural world for the time being, but also for the future. On the contrary, Lyons argued that economic law of profit and loss will mean nothing to future generations. If present generation today is focusing on gaining as huge profit as possible by exploiting natural resources with the help of technology, then the loss will be suffered by the coming generation.

The value of sustainability and concern for future generation shared by Oren Lyons in this oration is actually a warning to the audience. It is a warning so that people will not only be obsessed by the economic law of profit and lost. It is a warning so that technology will not mindlessly be used to outsource the natural world without thinking about the impact that will be suffered by the coming generation. 


\section{e. The Power of the Creator and the Natural Law}

Another statement containing Indigenous value found in Oren Lyons' oration is that power is not manifested in the human being, but in the Creator. Here is the quotation.

"Power is not manifesting in the human being. True power is in the Creator. If we continue to ignore the message by which we exist and we continue to destroy the source of our lives then our children will suffer." (Scharding, 2002: 93)

Within the statement, there are two connected ideas, i.e. belief in the power of the Creator and the natural law. The place of power in the Creator said by Lyons denotes the existence of theism in Haudenosaunee. They believed that all things have been placed here through the will or direction of the Creator or The Master of Life. Consequently, all things have a distinct purpose and are of equal value, although they may have different forms and functions (Cousins, 2004). When Oren Lyons said that power is not manifesting in the human being, he is trying to warn the audience that the power they seem to have over the natural world is actually the Creator's, thus, they have to follow the law, the natural law, in exercising that power.

Natural law is also a powerful influence in traditional Haudenosaunee understanding. Those who chose to ignore it, or toil against it, often suffered grave repercussions (Cousins, 2004). This principle is reflected in the later sentence of the above quotation. Oren Lyons said that people cannot excessively exploit the natural resource - or in his language: destroys the source of life, as it denies the equality of all living things created by the Creator, otherwise their children will suffer. This causal connection of destroying the source of live and the suffering of the children is one example of the working mechanism of natural law believed by Haudenosaunee.

Oren Lyons' sequential statement about the power of the Creator and natural law shows that there is close relation among the two things. The Creator governed the universe through the natural law.
Furthermore, natural law can function as a good control for human being that they will carefully outsource the natural world.

\section{f. Unity}

Importance of unity of spirit and of brotherhood among nations is also one of the Indigenous knowledge shared by Oren Lyons in his oration. Union such as United Nations is not something new for the Haudenosaunee. Hundred years before the formation of United Nations, Onondaga Nation, Mohawk Nation, Seneca Nation, Cayuga Nation, and Oneida Nation unified themselves under a confederacy. In this next quotation, Oren Lyons put this idea.

"There should be brotherhood, and the Haudennosaunee, Six Nations, the Iroquois, who were here fifty-three years ago to say the very same thing, the unity of spirit, of brotherhood. United Nations is nothing new to us. Our Confederacy is a thousand years old. The representation of the people is nothing new to us because that is whom we represent." (Scharding, 2002, p. 93)

Lyons chose the term unity of spirit and of brotherhood in the oration, instead of simply union. Haudenosaunee has a very long experience with this kind of unification as Lyons said that their confederacy is thousands years old of age.

The Five, later Six, Nations, did not only unite themselves in a union, but they also live under the same spiritual guidance: the Great Law of Peace cited by the Peacemaker who unite them. Furthermore, based on this Great Law of Peace, each Nations were divided into interlocking clan system, thus they can find members of their same clan (perceived as their brother and sisters) in other Haudenosaunee nations. These Great Law of Peace and interlocking clan system are means to unify the six nations of Haudenosaunee Confederacy in the spirit and in the brotherhood. This kind of union has been proven to give positive effect for the Haudenosaunee. It did not only bring peace to the Six Nations, but it had made them formidable for their neighboring nations, and thus it gave them power and authority. 
Lyons pointed out the importance of unity in spirit and in brotherhood among United Nations countries so that UN council can have the same power and authority to solve various problems faced by the world. The last sentence of the quotation is about representation of people within the union. Oren Lyons said that representation of people in UN is not something new; as in Haudenosaunee governmental system, they have been using the scheme of people representation since the day of the founding of confederacy.

Those are the six Indigenous knowledge identified in Oren Lyons oration "Where is the Eagle Seat?".

\section{Conclusion}

Looking at the Indigenous knowledge identified, the researcher found that Haudenosaunee Indigenous knowledge is indeed complex as it confirms the holistic nature of Indigenous knowledge. It does not separate the natural and the spiritual and it does not separate human kinds and other life forms. Haudenosaunee knowledge which is related to the natural world such as natural law and sustainability is interrelated to the knowledge of spirituality - as the Haudenosaunee believe that the natural world is imbued with spiritual force. They are also interrelated with the Haudenosaunee knowledge on human relations. Paradigm of interdependence or the web of life which views that every entity in this world is connected in reciprocal relationship led to the vision that every human is created equal; and belief that all elements in the natural world is created equal, including human, led to the command that human beings must consider the natural world in their decision making. Furthermore, Haudenosaunee Indigenous knowledge on spirituality governs the relation between human beings and the Creator and also governs the relation between human beings with other creation.

Haudenosaunee Indigenous knowledge which speaks about human relations, which is visible in Oren Lyons oration, emphasize the concept of equality and justice. This knowledge on human relations also put forward the importance of peace, harmony, and reconciliation among peoples. With the existence of peace and harmony among people, unity will be established. Unity is also emphasized in the oration. Unity among people is needed to address various problems which transcend national boundaries.

Haudenosaunee Knowledge which speaks about nature emphasizes the existence of natural law. Within this law, human being must maintain the harmony of the relationship of all being. They cannot act carelessly in outsourcing the natural world, otherwise they will suffer. Haudenosaunee Indigenous knowledge on natural law was put forward to promote sustainable lifestyle to save the world from continues environmental degradation.

Haudenosaunee Indigenous knowledge also speaks about the future generation. In Haudenosaunee culture, the generation yet unborn has a special place. In every consideration, the Haudenosaunee have to consider the impact of their decision on the future generation. The future generation, for Haudenosaunee means the continuation of their existence. The message concerning the future generation was put forward to remind the audience about the importance of sustainable lifestyle so that the future generation can also enjoy the natural resource enjoyed by their ancestors now. It is important to think of the fate of the future generation, as their existence means the continuation of human being as a species.

\section{References}

Cajete, Gregory. Native Science - Natural Laws of Interdependence. Santa Fee, New Mexico: Clear Light Publisher, 2000. Print.

Cousins, Michael. "Aboriginal justice: A Haudenosaunee approach." Native Law Centre Vol. 9, No. 1. 2004: 4. Print. 
Dorairaj, A. Joseph. "Paul Ricoeur's Hermeneutics of the Text." Indian Philosophical Quarterly XXVII No. 4. 2000: 403-410. Print.

Ghasemi, A., Taghinejad, M., Kabiri, A., Imani, M. " Ricoeur's Theory of Interpretation: A Method for Understanding Text (Course Text)." World Applied Sciences Journal 15, 2011: 1623-1629. 2011. Print.

Gonyea, Ray. Onondaga Portrait of Native People (pp. 11-32). New York: Syracuse University Press, 1986. Print.

Graymont, Barbara. The Iroquois Indians of North America. Philadelphia: Chelsea House Publishers, 2005. Print.

"Great Law of Peace". Haudenosaunee Iroquois Confederacy.Web. 22, 2015< http://haudenosaunee.ca/5.html>

Harris, Alexandra. \& Johnson, Tim. Haudenosaunee Guide for Educators. New York: National Museum of the American Indian, Smithsonian Institution, 2009. Print.

Hart, Michael. "Indigenous Worldviews, Knowledge, and Research: The Development of an Indigenous Research Paradigm." Journal of Indigenous Voices in Social Work, 2010:1-16. Print.

Hill, Sidney. (2004). "Neighbors of the Onondaga Nation, Working in Solidarity with the Onondaga Nation." peacecouncil.net 2004. Web. December 17, 2014.

Hudelson, P.M. "Culture and Quality: an Anthropological Perspective. "oxfordjournals.org Web. March 24, 2015.

Johansson, B. E. \& Mann, B. A. Encyclopedia of the Haudenosaunee. Westport: Greenwood Publishing, 2000. Print.

Johnson, Michael. Tribes of the Iroquois Confederacy. Oxford, UK: Osprey Publishing, 2003. Print.
Lopez, B. \& Lyons, Oren. "The Leadership Imperatives: An Interview with Oren Lyons." Manoa, Vol. 19, No. 2, Maps of Reconciliation: Literature and the Ethical Imagination, 2001. Print.

Lyons, Oren. "An Iroquoian Perspective." Learning to Listen to the Land. Ed. W. B. Willers. Washington D.C.: Island Press, 1991 p. 203. Print.

Nakashima, Douglas., \& Rou'e, Marie. "Indigenous Knowledge, Peoples and Sustainable Practice." Volume 5, Social and Economic Dimensions of Global Environmental Change, 2002: 314-324. Print.

Ricoeur, Paul. Interpretation Theory: Discourse and the Surplus of Meaning. Fort Worth, Texas: The Texas Christian University, 1976. Print.

Roland, Jon. "Constitution of the Iroquois Nations: The Great Binding Law, Gayanashagowa." constitution.org October 18, 1998. Web. November 18, 2014.

Scharding, Michael. Green Book of Meditations Volume 4: The ill AD and the Odd Essay. Northfield, Minnesota: Drynemetum Press, 2002. Print.

"Values". Haudenosaunee Confederacy. Web.November 18, 2014< http://www.haudenosauneeconfederacy .com/values.html>

Vien, John. "Teaching and Learning for a Sustainable Future." unesco.org. 2010. Web. February 19, 2015.

Welker, Glenn. "Iroquois Constitution". indigenouspeople.net. Web. May 26, 2014. 